\title{
Identification of putative methylotrophic and hydrogenotrophic methanogens within sedimenting material and copepod faecal pellets
}

\author{
Arlene K. Ditchfield ${ }^{1, *}$, Samuel T. Wilson ${ }^{1,3}$, Mark C. Hart ${ }^{1}$, Kevin J. Purdy ${ }^{2}$, \\ David H. Green ${ }^{1}$, Angela D. Hatton ${ }^{1, * *}$ \\ ${ }^{1}$ Scottish Association for Marine Science, Scottish Marine Institute, Oban, Argyll PA37 1QA, UK \\ ${ }^{2}$ School of Life Sciences, University of Warwick, Gibbet Hill, Coventry CV4 7AL, UK \\ ${ }^{3}$ Present address: Center for Microbial Oceanography: Research and Education (C-MORE), University of Hawaii Honolulu, \\ Hawaii 96822, USA
}

\begin{abstract}
In the present study, sedimenting particulate material and faecal pellets from natural and laboratory-reared copepods were examined for the presence of methanogenic Archaea. 16S rRNA gene sequences closely related to Methanogenium, Methanobacterium and Methanolobus spp. were detected, indicating the potential for different methanogenic metabolisms (hydrogenotrophic and methylotrophic methanogenesis) in these samples. The present study represents the first 16S rRNA gene-based identification of methanogens in copepod faecal pellets and importantly the first reported 16S rRNA-based occurrence of potentially hydrogenotrophic methanogens from marine particulate material, where it was previously thought that methylotrophic methanogens dominated methanogenesis. Anaerobic incubation experiments using sedimenting particulate material and copepod faecal pellets demonstrated active methane production and indicated that the associated methanogenic community was viable under the conditions tested.
\end{abstract}

KEY WORDS: Hydrogenotrophic methanogens $\cdot$ Methyltrophic methanogens $\cdot$ Copepod $\cdot$ Faecal pellets $\cdot$ Sedimenting particulate material $\cdot$ Methane production

\section{INTRODUCTION}

The discovery of super-saturated concentrations of methane, relative to atmospheric levels, within the marine pelagic environment (Lamontagne et al. 1973) and its apparent in situ biological production (Scranton \& Brewer 1977, Traganza et al. 1979, Ward et al. 1987, Damm et al. 2008, 2010) raises a number of fundamental questions regarding the nature and location of methane production and the microbes that mediate this process. To date, 2 hypotheses have been proposed for this oceanic methane paradox (Kiene 1991): (1) anaerobic methanogenesis is mediated by Archaea (Oremland 1979, Bianchi et al. 1992,
Marty 1993, Marty et al. 1997), and (2) methane is produced ('aerobic production') via metabolism of organic phosphonates under phosphate limitation (Karl et al. 2008) or metabolism of dimethylsulfoniopropionate where the nitrate:phosphate $(\mathrm{N}: \mathrm{P})$ ratio is low (Damm et al. 2010). The present study aimed to investigate the potential for the first of these hypotheses by using culture-independent methods to identify methanogen rRNA gene sequences and anaerobic incubation experiments to study the potential for methanogenesis to occur in sedimenting particles.

The existence of anoxic micro-sites in marine sedimenting particles, organic-rich faecal pellets and the 
digestive tracts of zooplankton could explain how methane production can occur in the oxygenated water column (Oremland 1979, Sieburth 1987, Bianchi et al. 1992, Marty 1993, Marty et al. 1997). Previous reports have provided evidence of in situ methane production associated with particulate material (e.g. Karl \& Tilbrook 1994, Tilbrook \& Karl 1995) and zooplankton blooms (Traganza et al. 1979, Damm et al. 2008). This has been further substantiated by measurements of methane production during incubation experiments with copepods (de Angelis \& Lee 1994), sedimenting particulate material and zooplankton faecal pellets (Bianchi et al. 1992, Marty 1993, Marty et al. 1997) and through the detection of methanogens and methanogen-like populations in pelagic material (Cynar \& Yayanos 1991, Sieburth et al. 1993, van der Maarel et al. 1999). To date, only members of the Methanosarcinaceae have been identified from marine pelagic samples. These organisms are known primarily for their ability to metabolise methylated compounds, and this, along with the potential for methanogens to be outcompeted by sulphate reducers for other common substrates (e.g. formate or $\mathrm{H}_{2}-\mathrm{CO}_{2}$ ), has led to the hypothesis that methanogenesis in the upper oceans occurs mainly via the metabolism of methylated compounds, such as the phytoplanktonderived methylamines and dimethylsulphide (Sieburth \& Donaghay 1993).

In addition, while methanogens were traditionally considered to be obligately anaerobic, therefore unlikely to survive in well-oxygenated waters, they have been shown to be metabolically active in environments that are not completely anoxic (e.g. Leadbetter et al. 1998, Gray et al. 2002). Moreover, some methanogen species, Methanomicrococcus, Methanobrevibacter (Tholen et al. 2007, Sprenger et al. 2007), Methanosarcina and Methanocella (Angel et al. 2011), have now been shown to survive and continue to produce methane under oxic conditions. These organisms have the ability to remove oxygen, thus creating micro-conditions appropriate for their growth (Tholen et al. 2007, Sprenger et al. 2007, Angel et al. 2011). This trait would potentially allow methanogenic species to survive and be metabolically active in the dynamic oxic/anoxic micro-environment of particulate material.

The present study aimed to determine if methanogenic Archaea were associated with sedimenting particulate material and copepod faecal pellets collected from Scottish sea lochs and to assess whether the indigenous methanogenic community was viable by measuring methane production under anoxic conditions.

\section{MATERIALS AND METHODS}

\section{Sampling}

Sedimenting particulate material and copepods were collected during the summer months (2006) from 2 interconnected sea lochs (Loch Creran, $56^{\circ} 31^{\prime} \mathrm{N}, 05^{\circ} 23^{\prime} \mathrm{W}$, and Loch Linnhe, $56^{\circ} 28^{\prime} \mathrm{N}$, $05^{\circ} 30^{\prime} \mathrm{W}$; salinity $\sim 30$ to $35 \mathrm{ppt}$ ) on the west coast of Scotland. A sediment trap (Leftley \& MacDougall 1991) was suspended in Loch Creran $\left(56^{\circ} 31.12^{\prime} \mathrm{N}\right.$, $05^{\circ} 22.34^{\prime} \mathrm{W}$ ) at a depth of $27 \mathrm{~m}$ (water depth $\sim 50 \mathrm{~m}$ ) for $24 \mathrm{~h}$ to obtain sedimenting particulate material for DNA analysis. Trap material was mixed for $10 \mathrm{~min}$ at $150 \mathrm{rpm}$ on an orbital shaker, then washed twice with sodium phosphate buffer (120 mM, pH 8.0) to remove extracellular nucleic acids (Tsai \& Olson 1991) before storage at $-80^{\circ} \mathrm{C}$.

To obtain sufficient material for methane production measurements, the sediment trap was redeployed at the same location for $4 \mathrm{~d}$ (8 to 11 June and 11 to 14 August 2006). After retrieval of the trap, sedimenting material from the collection tubes was pooled and siphoned through a $500 \mu \mathrm{m}$ mesh to remove zooplankton caught in the trap. Sedimenting particulate samples were stored on ice prior to microcosm preparation (see 'Methane production in sedimentary particulate material and faecal pellet microcosms').

Natural (field) and laboratory-reared copepods were collected from a vertical zooplankton trawl taken on 8 June 2006 from below the chlorophyll maximum in Loch Linnhe $\left(56^{\circ} 28.75^{\prime} \mathrm{N}, 05^{\circ}\right.$ $\left.30.10^{\prime} \mathrm{W}\right)$. Copepod populations were collected from Loch Linnhe (an interconnected loch) instead of Loch Creran as populations were greater at time of sampling in Loch Linnhe. Following field sampling, natural copepod populations were allowed to defecate for $3 \mathrm{~h}$, after which time faecal pellets were collected. Approximately 300 fresh faecal pellets (total wet weight $\approx 0.1 \mathrm{mg}$; average length $\sim 200 \mu \mathrm{m}$ ) were collected, examined by light microscopy, centrifuged at $13000 \times g$ for $10 \mathrm{~min}$ and stored at $-80^{\circ} \mathrm{C}$ prior to DNA extraction. Adult copepods Temora longicornis and Acartia clausi, also isolated from the zooplankton trawl, were maintained in the laboratory for $6 \mathrm{mo}$, using their natural prey Rhinomonas sp. and Oxyrrhis marina, prior to collection of faecal pellets. Faecal pellets harvested from the laboratory-reared copepods were collected and stored as above. Copepod faecal pellets were also collected from laboratoryreared adult $T$. longicornis for methane production 
Table 1. Temperature cycling parameters for PCR amplifications used in the present study (25 $\mu \mathrm{l}$ reaction volume)

\begin{tabular}{|c|c|c|c|c|c|c|c|}
\hline Primers & Hotstart & $\begin{array}{l}\text { PCR } \\
\text { step }\end{array}$ & Denaturation & Annealing & Extension & $\begin{array}{l}\text { No. of } \\
\text { cycles }\end{array}$ & $\begin{array}{c}\text { Final } \\
\text { extension }\end{array}$ \\
\hline \multirow{2}{*}{$\begin{array}{l}\text { Arch 1Af } \\
\text { Arch1404r } \\
\text { touchdown }\end{array}$} & \multirow{2}{*}{$5 \mathrm{~min}, 95^{\circ} \mathrm{C}$} & 1 & $\begin{array}{c}1 \mathrm{~min}, 94^{\circ} \mathrm{C} \\
(9 \text { cycles })\end{array}$ & $\begin{array}{c}1 \mathrm{~min}, 63^{\circ} \mathrm{C} \\
\text { reduce } 1^{\circ} \mathrm{C} \text { cycle }^{-1} \\
(9 \text { cycles })\end{array}$ & $\begin{array}{c}1 \mathrm{~min}, 72^{\circ} \mathrm{C} \\
(9 \text { cycles })\end{array}$ & \multirow{2}{*}{33} & \multirow{2}{*}{$5 \min , 72^{\circ} \mathrm{C}$} \\
\hline & & 2 & $\begin{array}{l}30 \mathrm{~s}, 92^{\circ} \mathrm{C} \\
(24 \text { cycles })\end{array}$ & $\begin{array}{l}30 \mathrm{~s}, 53^{\circ} \mathrm{C} \\
(24 \text { cycles })\end{array}$ & $\begin{array}{l}30 \mathrm{~s}, 72^{\circ} \mathrm{C} \\
(24 \text { cycles })\end{array}$ & & \\
\hline \multirow{2}{*}{$\begin{array}{l}\text { Arch 1Af } \\
\text { Arch1100r }\end{array}$} & \multirow{2}{*}{$5 \min , 95^{\circ} \mathrm{C}$} & 1 & $\begin{array}{c}1 \mathrm{~min}, 94^{\circ} \mathrm{C} \\
(9 \text { cycles })\end{array}$ & $\begin{array}{c}1 \mathrm{~min}, 50^{\circ} \mathrm{C} \\
(9 \text { cycles })\end{array}$ & $\begin{array}{c}1 \mathrm{~min}, 72^{\circ} \mathrm{C} \\
(9 \text { cycles })\end{array}$ & \multirow{2}{*}{33} & \multirow{2}{*}{$5 \min , 72^{\circ} \mathrm{C}$} \\
\hline & & 2 & $\begin{array}{l}30 \mathrm{~s}, 92^{\circ} \mathrm{C} \\
(24 \text { cycles })\end{array}$ & $\begin{array}{l}30 \mathrm{~s}, 50^{\circ} \mathrm{C} \\
(24 \text { cycles })\end{array}$ & $\begin{array}{l}30 \mathrm{~s}, 72^{\circ} \mathrm{C} \\
(24 \text { cycles })\end{array}$ & & \\
\hline $\begin{array}{l}\text { ARD-F } \\
\text { ARD-R }\end{array}$ & $5 \min , 95^{\circ} \mathrm{C}$ & 1 & $30 \mathrm{~s}, 95^{\circ} \mathrm{C}$ & $30 \mathrm{~s}, 55^{\circ} \mathrm{C}$ & $1 \mathrm{~min}, 60^{\circ} \mathrm{C}$ & 26 & $10 \mathrm{~min}, 60^{\circ} \mathrm{C}$ \\
\hline
\end{tabular}

measurements (see 'Methane production in sedimentary particulate material and faecal pellet microcosms').

\section{DNA extraction and PCR amplification of 16S rRNA genes}

DNA was extracted from the sedimenting particles and faecal pellets following the procedure of van der Maarel et al. (1998) with minor modifications; specifically, the phenol chloroform step was repeated twice, and nucleic acids were ethanol precipitated before resupension in $100 \mu \mathrm{l}$ of Tris-ethylenediaminetetraacetic acid (TE) buffer. Euryarchaeotal 16S rRNA gene sequences were amplified using the semi-nested PCR described by Munson et al. (1997). It should be noted that the primers used in the present study are not universal for all Archaea but have been shown to amplify all known groups of methanogens (Munson et al. 1997). First round amplification was performed using primers Arch 1Af (5'TCY GKT TGA TCC YGS CRG AG-3') and Arch 1404r (5'-CGG TGT GTG CAA GGR GC-3'; Munson et al. 1997) followed by a semi-nested PCR amplification with the same forward primer (Arch 1Af) and Arch 1100r (5'-TGG GTC TCG CTC GTT G-3'; Embley et al. 1992). Five replicate reactions from the first round of PCR were pooled (to avoid stochastic biases; Wagner et al. 1994) and concentrated to $20 \mu \mathrm{l}$ with Montage PCR purification columns (Millipore). Replicate $2 \mu \mathrm{l}$ aliquots of the cleaned PCR products were used in the second round of the semi-nested amplification. PCR cycling parameters are given in Table 1.

\section{Cloning and sequencing of 16S rRNA gene fragments}

16S rRNA gene fragments were cloned using pGEM-T Easy vector (Promega) and transformed into Escherichia coli DH5 $\alpha$ cells. Random colonies were picked from each clone library, and the 16S rRNA gene inserts were reamplified using vector-based primers (ARD-F 5'-GCC ATG GCG GCC GCG GGA ATT-3' and ARD-R 5'-AGG CGG CCG CGA ATT CAC TAG-3'; PCR conditions given in Table 1). Restriction fragment length polymorphism (RFLP) was employed to screen clone PCR products ( 40 clones from each library) and identify different clone types. PCR products were digested with RsaI (Promega) for $15 \mathrm{~h}$ according to the manufacturer's instructions, and the restricted fragments were separated on a $2.5 \%$ Metasieve agarose gel. The restriction fragments from each clone were visually compared to each other and restriction patterns from environmental clones closely related to isolated Methanogenium (accession no. AY177815) and Methanolobus spp. (AY177812; Purdy et al. 2003). One or more clone representatives of each RFLP type detected from each clone library were sequenced using BigDye ${ }^{\circledR}$ Terminator v1 chemistry (Applied Biosystems) and analysed on an ABI Prism 377 DNA sequencer (Sequencing Facility, Natural History Museum, London).

\section{Phylogenetic analysis of the 16S rRNA gene clone sequences}

The identity of each sequenced clone was initially established by BLASTn analysis (Altschul et al. 


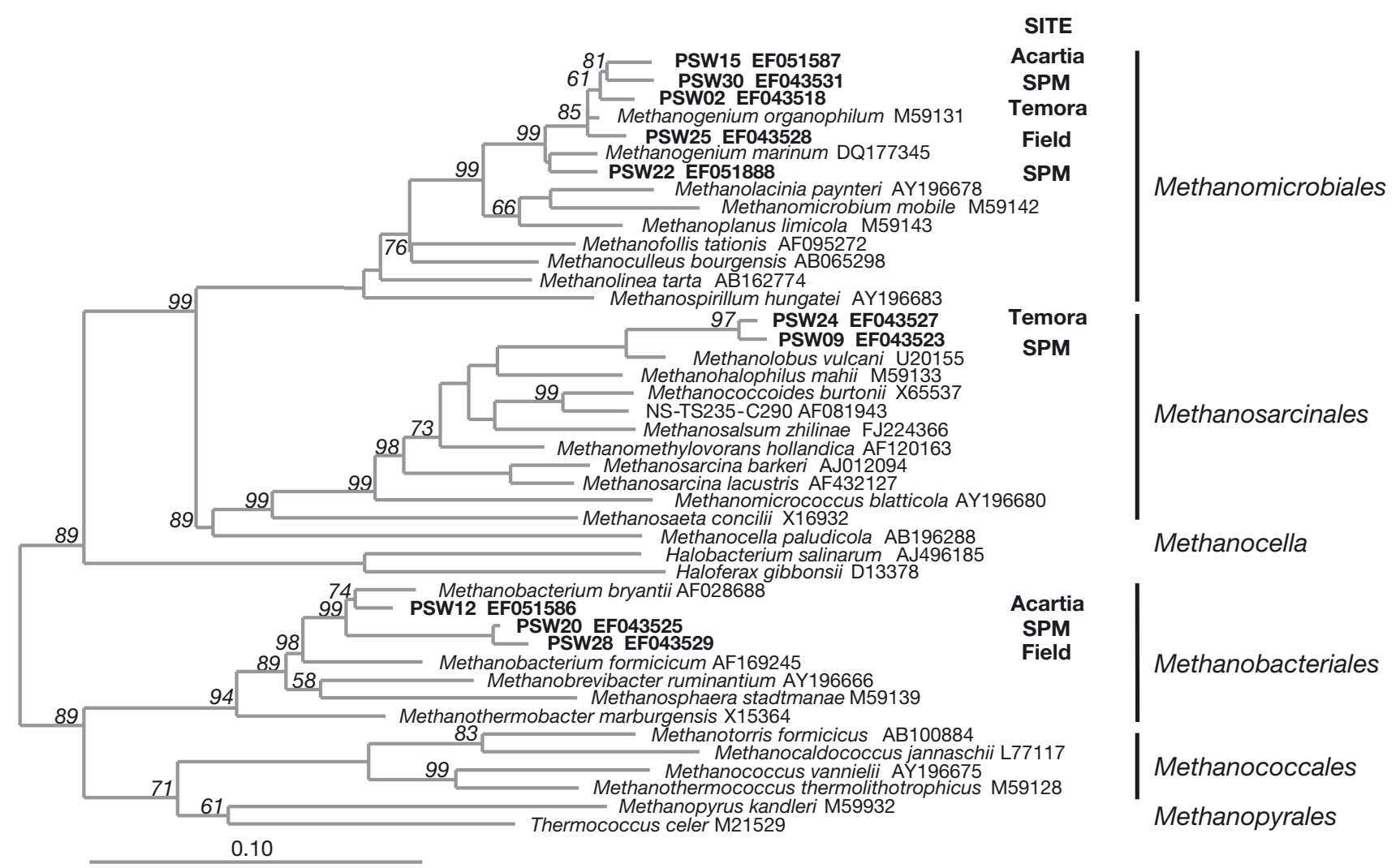

Fig. 1. Phylogenetic distance tree based on 16S rRNA gene sequences ( 900 bp) showing the relationships among methanogenic reference taxa and clones from sedimenting particulate material (SPM), faecal pellets of natural (Field) and laboratory-reared copepods (Acartia clausi: Acartia; Temora longicornis: Temora). Sequences detected in the present study are shown in bold, bootstrap values $>50 \%$ are shown at nodes, and GenBank accession numbers are given after each name

1997). The partial 16S rRNA gene clone sequences ( $900 \mathrm{bp}$ ) from the particulate and faecal pellet samples were aligned with published 16S rRNA gene sequences from Euryarchaeota using ARB (ARBuntu 2.0, Ribocon; Ludwig et al. 2004). The ARB FastAligner program was used for initial sequence alignment, and all alignments were then verified manually. A phylogenetic distance tree was generated using the Jukes and Cantor correction (Jukes \& Cantor 1969) and the neighbour-joining algorithm (Saitou \& Nei 1987) in ARB. Bootstrap (1000 replicates; Felsenstein 1988) values $>50 \%$ are shown at nodes in Fig. 1.

\section{Nucleotide sequence accession numbers}

The 16S rRNA partial sequences obtained from the sedimenting particulate and faecal pellet samples in the present study are available from the European Molecular Biology Laboratory (EMBL) nucleotide sequence database (accession numbers EF043518,
EF043523 to EF043529, EF043531 and EF051586 to EF051588).

\section{Methane production in sedimentary particulate material and faecal pellet microcosms}

Anaerobic incubation experiments were set up to investigate the production of methane from particulate material. Sediment trap material $(\sim 1 \mathrm{~g}$ wet weight; $\sim 0.4 \mathrm{~g}$ dry weight) was decanted into each triplicate sterile $15 \mathrm{ml}$ glass vials. Vials were filled with aged $0.5 \mu \mathrm{m}$-filtered autoclaved seawater (collected from $56^{\circ} 37.19^{\prime} \mathrm{N}, 06^{\circ} 23.53^{\prime} \mathrm{W}$, near Tiree; salinity 30 to $35 \mathrm{ppt}$ ) and sealed with crimp top teflon lined stoppers. A $4 \mathrm{ml}$ headspace of oxygen-free nitrogen was introduced into the microcosms by degassing through a needle, and at the same time, the seawater was expelled using another needle. Controls consisted of filtered seawater only and an autoclaved sedimenting particulate control. Sediment trap microcosms were incubated in the dark at 
$13^{\circ} \mathrm{C}$ (ambient seawater temperature when sampled) and manually mixed twice daily. Anaerobic incubations using faecal pellet material (see 'Sampling') were prepared as follows. Approximately 600 faecal pellets ( 0.2 mg wet weight, dry weight evaluated to be $30 \%$ of the wet weight; Morales 1987) were transferred to each triplicate $15 \mathrm{ml}$ glass vial, and these were prepared and conducted as above with the modification that the samples were reduced by the addition of sodium dithionite (Sigma Aldrich; final conc. $200 \mu \mathrm{mol})$ to ensure that the reducing conditions required for methanogenesis were achieved (Oremland 1979). Headspace samples were removed every 1 to $2 \mathrm{~d}$ using a gas tight syringe and replaced by oxygen-free nitrogen. Methane was analysed by gas chromatography (Varian 3400cx GC fitted with a $1.8 \mathrm{~m} \times 0.3 \mathrm{~cm}$ packed molecular sieve column and a flame ionization detector, operated with temperature program of 45 to $80^{\circ} \mathrm{C}$; Wilson 2007) and calibrated using methane standards from Alltech Associates. The total methane production in the microcosms (water- and gas-phase) and methane production rates were determined from the headspace concentration using the calculations of Kampbell \& Vandegrift (1998).

\section{RESULTS}

\section{Methanogenic populations in sedimenting particulate material and faecal pellets}

The semi-nested euryarchaeotal-specific PCR (Table 1) successfully amplified 16S rRNA gene sequences from DNA extracted from all samples. Only 3 distinct RFLP patterns were detected in all of the clone libraries (data not shown), and representative clones from each library were sequenced.

While all sequenced clones were most closely related to other environmental clones (from Antarctic sediments and termite guts; Table 2), they also had high sequence identity with cultured methanogens (96 to 99\%; Fig. 1, Table 2) from the genera Methanogenium, Methanobacterium and Methanolobus. All 4 clone libraries were dominated by Methanogenium organophilum-like sequences, with 56 to $98 \%$ of clones in the 4 libraries closely related to this organism. In the 3 faecal pellet libraries, 2 different methanogen sequence types groups were detected: Methanogenium organophilum- and Methanolobus vulcani-like sequences in Temora longicornis faecal pellets and Methanogenium organophilum- and

Table 2. Nearest neighbour (clones and cultured representatives) of the euryarchaeotal cloned sequences identified from sedimenting particulate material and faecal pellets from laboratory-reared and field Temora longicornis and Acartia clausi samples

\begin{tabular}{|c|c|c|c|c|}
\hline $\begin{array}{l}\text { Sample type and nearest neighbour } \\
\text { (clones and cultured representatives) }\end{array}$ & Clone & $\begin{array}{c}\text { Similarity } \\
(\%)\end{array}$ & $\begin{array}{l}\text { Clone frequency } \\
(\%)\end{array}$ & Origin of relative \\
\hline \multicolumn{5}{|l|}{ Sedimenting particulate material $^{\mathrm{a}}$} \\
\hline Clone LH14 (AY177806) & PSW22 & \multirow[t]{2}{*}{$97-99$} & \multirow[t]{2}{*}{78} & \multirow{2}{*}{$\begin{array}{l}\text { Antarctic sediment } \\
\text { (Purdy et al. 2003) }\end{array}$} \\
\hline Methanogenium organophilum & PSW30 & & & \\
\hline Clone Mg38 (AB181818) & \multirow[t]{2}{*}{ PSW20 } & \multirow[t]{2}{*}{99} & \multirow[t]{2}{*}{19} & \multirow{2}{*}{$\begin{array}{l}\text { Termite guts } \\
\text { (Deevong et al. 2004) }\end{array}$} \\
\hline Methanobacterium bryantii & & & & \\
\hline Clone SB05 (AY177812) & \multirow[t]{2}{*}{ PSW24 } & \multirow[t]{2}{*}{97} & \multirow[t]{2}{*}{3} & \multirow{2}{*}{$\begin{array}{l}\text { Antarctic sediment } \\
\text { (Purdy et al. 2003) }\end{array}$} \\
\hline Methanolobus vulcani & & & & \\
\hline \multicolumn{5}{|c|}{ Faecal pellets from lab-reared T. longicornis ${ }^{b}$} \\
\hline Clone LH14 (AY177806) & PSW02 & 99 & 98 & \multirow{4}{*}{$\begin{array}{l}\text { Antarctic sediment } \\
\text { (Purdy et al. 2003) }\end{array}$} \\
\hline Methanogenium organophilum & & & & \\
\hline Clone SB05 (AY177812) & \multirow[t]{2}{*}{ PSW09 } & \multirow[t]{2}{*}{96} & \multirow[t]{2}{*}{2} & \\
\hline Methanolobus vulcani & & & & \\
\hline \multicolumn{5}{|l|}{ Faecal pellets from lab-reared $A$. clausi ${ }^{\mathrm{C}}$} \\
\hline Clone LH14 (AY177806) & \multirow[t]{2}{*}{ PSW15 } & \multirow[t]{2}{*}{99} & \multirow[t]{2}{*}{56} & \multirow{2}{*}{$\begin{array}{l}\text { Antarctic sediment } \\
\text { (Purdy et al. 2003) }\end{array}$} \\
\hline Methanogenium organophilum & & & & \\
\hline Clone Mg38 (AB181818) & \multirow[t]{2}{*}{ PSW12 } & \multirow[t]{2}{*}{99} & \multirow[t]{2}{*}{44} & \multirow{2}{*}{$\begin{array}{l}\text { Termite guts } \\
\text { (Deevong et al. 2004) }\end{array}$} \\
\hline Methanobacterium bryantii & & & & \\
\hline \multicolumn{5}{|l|}{ Faecal pellets from field copepods ${ }^{\mathrm{d}}$} \\
\hline Clone LH14 (AY177806) & \multirow[t]{2}{*}{ PSW25 } & \multirow[t]{2}{*}{99} & \multirow[t]{2}{*}{97} & \multirow{2}{*}{$\begin{array}{l}\text { Antarctic sediment } \\
\text { (Purdy et al. 2003) }\end{array}$} \\
\hline Methanogenium organophilum & & & & \\
\hline Clone Mg38 (AB181818) & \multirow[t]{2}{*}{ PSW28 } & \multirow[t]{2}{*}{98} & \multirow[t]{2}{*}{3} & \multirow{2}{*}{$\begin{array}{l}\text { Termite guts } \\
\text { (Deevong et al. 2004) }\end{array}$} \\
\hline Methanobacterium bryantii & & & & \\
\hline Number of clones per sample: ${ }^{a} n=4$ & 40 & & & \\
\hline
\end{tabular}


Methanobacterium bryantii-like sequences in Acartia clausi and natural faecal pellets (Fig. 1, Table 2). All 3 sequence types were observed in the sedimenting particulate material.

\section{Methanogenic potential of sedimenting particulate material and faecal pellets}

To determine whether the indigenous methangenic population was viable in the faecal pellets and sedimentary particulate material, methane production was measured in anaerobic microcosm experiments. Headspace methane was detected in all microcosms containing sedimenting particulate material and Temora longicornis faecal pellets (Fig. 2). Methane production in the sedimentary particulate material microcosms was evident from Day 1, with headspace methane in both samples reaching a maximum at Day 5 (maximum methane production rates $0.032 \pm 0.005$ and $0.006 \pm 0.002 \mu \mathrm{mol} \mathrm{CH}_{4} \mathrm{~g}^{-1} \mathrm{~d}^{-1}$ for June and August respectively). In microcosm experiments using faecal pellets from $T$. longicornis, the maximum methane production rates were $1.23 \pm 0.56 \mu \mathrm{mol} \mathrm{CH}_{4} \mathrm{~g}^{-1} \mathrm{~d}^{-1}$,

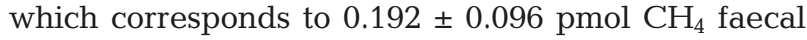
pellet $^{-1} \mathrm{~d}^{-1}$. This observed production of methane in the microcosms suggests that the indigenous population was viable under the conditions tested; however, it does not show specifically which methanogenic pathways were involved (methylotrophic and/or hydrogenotrophic). No significant production of methane was observed in the control incubations containing filtered seawater only (no sedimenting particulate material or faecal pellets) or filtered seawater plus autoclaved sedimentary particulate material.

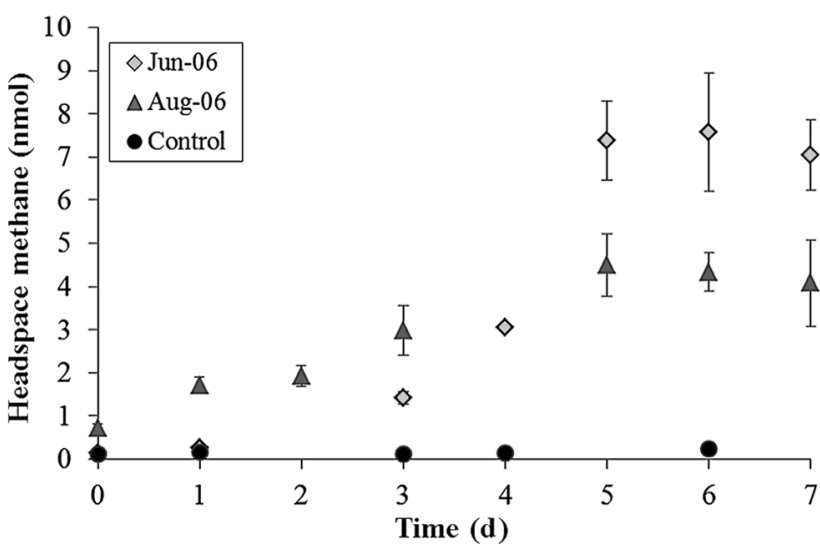

Fig. 2. Headspace methane production in anaerobic incubations of sedimenting particulate material (collected at 2 time points, June and August 2006). Data are the mean of triplicate experiments (error bars $= \pm 1 \mathrm{SD}$ ). Where error bars are not visible, they are smaller than symbols

\section{DISCUSSION}

Culture-independent analysis of sedimentary particulate material and copepod faecal pellets identified 3 different methanogen sequence types (Fig. 1): hydrogenotrophic Methanogenium- and Methanobacterium-like sequences and methylotrophic Methanolobus-like sequences. Although all 3 methanogen genera have previously been detected in marine sediments (Liu \& Whitman 2008), our study represents the first 16S rRNA-based identification of methanogens in copepod faecal pellets, which Marty (1993) and de Angelis \& Lee (1994) suggested may have originated in the copepod gut, and extends the diversity of methanogen-like sequences that have been found in sedimenting particulate material. Furthermore, the diversity revealed by the present study suggests that there is the potential for both hydrogenotrophic and methylotrophic methanogenesis to occur within these environments rather than methane production being limited to the degradation of methyl compounds, as had been hypothesised previously (Kiene 1988, de Angelis \& Lee 1994, van de Maarel et al. 1999, Damm et al. 2008). In fact, the 2 hydrogenotrophic genera Methanogenium and Methanobacterium (Whitman et al. 2006) dominated all 4 clone libraries and therefore are potentially important members of the methanogenic communities in sedimenting particulate material. These results support the findings of Marty (1993), who reported methylotrophic and hydrogenotrophic methanogenesis in some enrichments derived from sedimenting particles and zooplankton. The presence of potentially active hydrogenotrophic methanogens in these sulphate-rich anaerobic micro-environments would place these organisms in direct competition for hydrogen with sulphate-reducing bacteria, and yet the present work and other studies (e.g. Marty 1993) suggest that methane production in the upper ocean could occur via both of these methanogenic pathways.

Sedimenting particles are potential hotspots of microbial activity (Simon et al. 2002), and the detection of methanogen sequences in sedimenting particulate material and copepod faecal pellets suggests that sufficiently anoxic conditions can exist in these particles. Furthermore, there is good evidence supporting the existence of anaerobic conditions in the oxygenated pelagic environment, such as detection of anaerobic organisms (Bianchi et al. 1992), the products of anaerobic processes (e.g. sulphide; Shanks \& Reeder 1993) and the existence of anoxic micro-sites (Alldredge \& Cohen 1987). Tang et al. 
(2011) have also recently observed oxygen undersaturation and steep oxygen gradients culminating in complete anoxia along the guts of 2 types of copepod (Calanus hyperboreus and C. glacialis). However, the occurrence of anoxic microsites in copepod faecal pellets and sedimenting material has been questioned. Micro-electrode measurements in marine faecal pellets and theoretical mass balance calculations indicate that anoxia within pelagic particulate material is limited to larger macro-aggregates $(>600 \mu \mathrm{m})$ under specific environmental conditions (Simon et al. 2002, Ploug et al. 1997, Ploug \& Jørgensen 1999). Ploug et al. (1997) suggested that anoxic conditions are ephemeral and that, due to the dynamic nature of the particulate environment, slowgrowing obligately anaerobic methanogens would not survive. Despite this, sequences closely related to methanogens were repeatedly recovered from Temora longicornis and Acartia clausi faecal pellets that measure, on average, only $200 \mu \mathrm{m}$ in length. Whilst the presence of 16S rRNA gene sequences does not indicate that the methanogens were active, we did demonstrate methane production from $T$. longicornis faecal pellet incubations, indicating viability of the indigenous population if provided with suitable conditions. These results confirm previous findings of methane production associated with incubation experiments of copepod faecal pellets and particulate material (Bianchi et al. 1992, Marty 1993,
Marty et al. 1997). However, in the present study, methane production was demonstrated in all samples (Table 3) at ambient seawater temperatures, over relatively short timescales $(7 \mathrm{~d})$ and without any discernible lag in methane production. In contrast, previous studies produced inconsistent results $(0$ to $100 \%$ of samples with detectable methane; Bianchi et al. 1992, Marty 1993) and used long incubations (up to $40 \mathrm{~d}$; Bianchi et al. 1992). In the present study, the rapid (production after $1 \mathrm{~d}$ ) and consistent (100\% of samples with detectable methane) response of the incubations suggests that the methanogenic community was active within the sedimentary particulate material and copepod faecal pellets under the anaerobic conditions tested.

It has also been hypothesised that pelagic methane may be produced via aerobic decomposition (see comment on aerobic decomposition by Grossart et al. 2011) of phosphorus-containing organic compounds, specifically phosphonates (Karl et al. 2008), under conditions of phosphate depletion. This pathway was first identified in 1979 by Daughton et al., who observed that a strain of Pseudomonas testosteroni could grow using methylphosphonate as a phosphorous source, with the aerobic cleavage of the C-P bond resulting in the release of methane. In 2008, Karl et al. showed the microbial breakdown of methylphosphonate in phosphate-stressed seawater samples, providing evidence for unconventional methano-

Table 3. Comparison of methane production in anaerobic incubation experiments of sediment trap particulate material and copepod faecal pellets under differing conditions. Direct comparisons of faecal pellet rates are not possible as other studies express the rates per $\mathrm{ml}$ of faecal pellet suspension not per gram, and sodium dithionite was added as a reducing agent in the present study but not in other studies. SPM: sedimenting particulate material

\begin{tabular}{|c|c|c|c|c|c|}
\hline Study & $\begin{array}{l}\text { Sample type and } \\
\text { no. of samples }\end{array}$ & $\begin{array}{l}\text { Time } \\
\text { (d) }\end{array}$ & $\begin{array}{l}\text { Temp. } \\
\left({ }^{\circ} \mathrm{C}\right)\end{array}$ & $\begin{array}{l}\% \text { of sample with } \\
\text { detectable } \mathrm{CH}_{4}\end{array}$ & $\begin{array}{l}\text { Methane production } \\
\text { rate }\end{array}$ \\
\hline $\begin{array}{l}\text { Bianchi } \\
\text { et al. } \\
(1992)\end{array}$ & $\begin{array}{l}\qquad \operatorname{SPM}(\mathrm{n}=2) \\
\text { Faecal pellets }(\mathrm{n}=2)\end{array}$ & 40 & $\begin{array}{l}15 \\
30 \\
15 \\
30\end{array}$ & $\begin{array}{c}0 \\
100 \\
0 \\
50\end{array}$ & 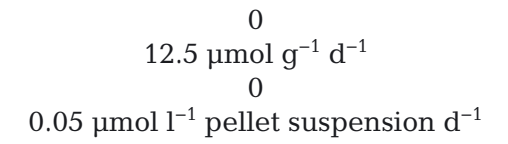 \\
\hline $\begin{array}{l}\text { Marty } \\
(1993)^{a}\end{array}$ & $\begin{array}{l}\text { SPM }(40 m \text { trap, } n=4) \\
\text { SPM }(80 m \text { trap, } n=10) \\
\text { Faecal pellets }(n=16)\end{array}$ & 30 & $\begin{array}{c}25 \\
\text { (in situ) }\end{array}$ & $\begin{array}{c}0 \\
20 \\
25\end{array}$ & $\begin{array}{c}0 \\
5.3 \mu \mathrm{mol} \mathrm{l}^{-1} \mathrm{~d}^{-1} \\
<0.001 \mu \mathrm{mol} \mathrm{l^{-1 }} \text { pellet suspension } \mathrm{d}^{-1}\end{array}$ \\
\hline $\begin{array}{l}\text { Present } \\
\text { study }\end{array}$ & $\begin{array}{c}\text { SPM (June } \mathrm{n}=3 \text { ) } \\
\text { SPM (August } \mathrm{n}=3 \text { ) } \\
\text { Faecal pellets }^{\mathrm{b}}(\mathrm{n}=3)\end{array}$ & 7 & $\begin{array}{c}13 \\
\text { (in situ) }\end{array}$ & $\begin{array}{l}100 \\
100 \\
100\end{array}$ & $\begin{aligned} 0.032 & \pm 0.005 \mu \mathrm{mol} \mathrm{g}-1 \mathrm{~d}^{-1} \\
0.006 & \pm 0.002 \mu \mathrm{mol} \mathrm{g}{ }^{-1} \mathrm{~d}^{-1} \\
1.23 & \pm 0.56 \mu \mathrm{mol} \mathrm{g} \mathrm{d}^{-1} \mathrm{~d}^{-1}\end{aligned}$ \\
\hline \multicolumn{6}{|c|}{$\begin{array}{l}{ }^{a} \text { Marty et al. (1997) also detected methane production in particulate incubation experiments, but results were expressed as } \\
\text { the amount of methane produced per tube not as rates of production (sediment trap } 3 \text { to } 11 \mathrm{nmol} \mathrm{CH}_{4} \text { per tube in } 30 \% \text { of } \\
\text { samples, and faecal pellets } 4 \text { to } 125 \mathrm{nmol} \mathrm{CH}_{4} \text { per tube in } 36 \% \text { of samples) } \\
\text { b The rate of methane production in the faecal pellets in the present study corresponds to } 0.192 \pm 0.096 \text { pmol faecal } \\
\text { pellet } \mathrm{d}^{-1}\end{array}$} \\
\hline
\end{tabular}


genesis (Ingall 2008). They showed that marine bacteria may be capable of using methylphosphonate, the simplest form of phosphonates, as their sole phosphorous source in the absence of phosphate and suggested that increased nutrient limitation could promote the use of phosphonates (Karl et al. 2008). This pathway depends on both the limitation of phosphate and the presence of methylphosphonate, and there is now evidence for the presence of phosphonates in the diazotroph Trichodesmium (Dyhrman et al. 2009) and, interestingly, sinking marine particles (Paytan et al. 2003, Benitez-Nelson et al. 2004). However, it has not yet been fully clarified how much of this phosphonate pool is made up of methylphosphonate. Damm et al. (2010) also proposed an 'aerobic' methane production pathway. The authors of this study demonstrated a relationship between DMSP removal, methane production and low N:P ratios, but the main pathway involved was not fully elucidated. The identification of these pathways and the suggestion that they may help address the ocean methane paradox reinforce the need for further research to understand the mechanisms contributing to methane production in the oceans. Due to the coastal location of Loch Creran, neither nitrate or phosphate were limited in the water column or particulate material (K. Black pers. comm.), suggesting that the nutrient-limited pathways proposed by Karl et al. (2008) and Damm et al. (2010) may play less of a role in the production of methane in these sites. It is highly likely, however, that both the 'aerobic' and anaerobic pathways exist and may fill specific niches contributing to the production of methane in different oceanic regions, but without further research into both pathways, we are unlikely to unravel the ocean methane paradox.

The recent work of Grossart et al. (2011) demonstrated active methanogenesis in the oxygenated water column of a freshwater lake, including the detection of hydrogenotrophic/acetoclastic methanogens and mcrA gene activity, supporting methane production by Archaeal methanogens. Importantly, this demonstrates that methanogenesis can occur in the oxygenated regions of the water column, and it is not improbable that this process also occurs in the ocean's surface. The sedimenting material and faecal pellet samples analysed in the present study were treated to create anoxic conditions to maximise the potential for methanogenesis. As analysis of dissolved oxygen concentration was not conducted, we cannot say whether methane production occurred in the presence of residual oxygen, as could potentially occur if the results of Grossart et al. (2011) can be applied to the marine environment.
In summary, the present study identified methanogen genera that have not been reported previously in marine sedimenting material or copepod faecal pellets, including, for the first time, potentially hydrogenotrophic methanogens. Furthermore, methane production measured in particulate material incubated under anaerobic conditions demonstrated the viability of the associated methanogenic community. The recovery of methanogen 16S rRNA gene sequences, including those of hydrogenotrophic methanogens, from material theoretically too small to host anaerobic processes suggests that the 'oceanic methane paradox' is still some way from being resolved. Work in this laboratory is currently underway to investigate the contribution of different metabolic pathways to methane production.

Acknowledgements. We thank L. Proctor for advice, K. Willis and H. Orr for help with maintaining copepods in the laboratory, CCAP for providing phytoplankton and the crew of RV 'Seol Mara' for their help. This work was funded by a UHI Millennium Institute PhD studentship, the SAMS Core Programme 2006 and NERC (NE/DO11213/1 \& NE/H024131/1). K.J.P. was funded by the Marie Curie Actions of the EU Framework Programme 6 (MicroComXT, a Marie Curie Excellence Team MEXT-CT-2005- 024112).

\section{LITERATURE CITED}

Alldredge AL, Cohen Y (1987) Can microscale chemical patches persist in the sea? Microelectrode study of marine snow and fecal pellets. Science 235:689-691

Altschul SF, Madden TL, Schaffer AA, Zhang J and others (1997) Gapped BLAST and PSI-BLAST: a new generation of protein database search engines. Nucleic Acids Res 25:3389-3402

Angel R, Matthies D, Conrad R (2011) Activation of methanogenesis in arid biological soil crusts despite the presence of oxygen. PLoS ONE 6:1-8

- Benitez-Nelson CR, O'Neill L, Kolowith LC, Pellechia P, Thunell R (2004) Phosphonates and particulate organic phosphorus cycling in an anoxic marine basin. Limnol Oceanogr 49:1593-1604

Bianchi M, Marty D, Teyssie JL, Fowler SW (1992) Strictly aerobic and anaerobic bacteria associated with sinking particulate matter and zooplankton fecal pellets. Mar Ecol Prog Ser 88:55-60

> Cynar FJ, Yayanos AA (1991) Enrichment and characterization of a methanogenic bacterium from the oxic upper layer of the ocean. Curr Microbiol 23:89-96

$>$ Damm E, Kiene RP, Schwarz J, Falck E, Dieckmann G (2008) Methane cycling in arctic shelf water and its relationship with phytoplankton biomass and DMSP. Mar Chem 109: 45-59

> Damm E, Helmke E, Thomas S, Schauer U, Nothig E, Bakker K, Kiene RP (2010) Methane production in aerobic oligotrophic surface waters in the central Arctic Ocean. Biogeosciences 7:1099-1108

Daughton CG, Cook AM, Alexander M (1979) Bacterial conversion of alkylphosphonates to natural products via 
carbon-phosphorus bond cleavage. J Agric Food Chem 27:1375-1382

de Angelis MA, Lee C (1994) Methane production during zooplankton grazing on marine phytoplankton. Limnol Oceanogr 39:1298-1308

Deevong P, Hattori S, Yamada A, Trakulnaleamsai S and others (2004) Isolation and detection of methanogens from the gut of higher termites. Microbes Environ 19:221-226

Dyhrman ST, Benitez-Nelson CR, Orchard ED, Haley ST, Pellechia PJ (2009) A microbial source of phosphonates in oligotrophic marine systems. Nat Geosci 2:696-699

Embley TM, Finlay BJ, Thomas RH, Dyal PL (1992) The use of ribosomal-RNA sequences and fluorescent probes to investigate the phylogenetic positions of the anaerobic ciliate Metopus palaeformis and its archaeobacterial endosymbiont. J Gen Microbiol 138:1479-1487

Felsenstein J (1988) Phylogenies from molecular sequences: inference and reliability. Annu Rev Genet 22:521-565

Gray ND, Miskin IP, Kornilova O, Curtis TP, Head IM (2002) Occurrence and activity of Archaea in aerated activated sludge wastewater treatment plants. Environ Microbiol 4:158-168

> Grossart HP, Frindte K, Dziallas C, Eckert W, Tang KW (2011) Microbial methane production in oxygenated water column of an oligotrophic lake. Proc Natl Acad Sci USA 108:19657-19661

Ingall ED (2008) Oceanography: making methane. Nat Geosci 1:419-420

Jukes TH, Cantor CR (1969) Evolution of protein molecules. In: Munro HN (ed) Mammalian protein metabolism. Academic Press, New York, NY, p 21-132

Kampbell DH, Vandegrift SA (1998) Analysis of dissolved methane, ethane, and ethylene in ground water by a standard gas chromatographic technique. J Chromatogr Sci 36:253-256

Karl DM, Tilbrook BD (1994) Production and transport of methane in oceanic particulate organic matter. Nature 368:732-734

Karl DM, Beversdorf L, Bjorkman KM, Church MJ, Martinez A, Delong EF (2008) Aerobic production of methane in the sea. Nat Geosci 1:473-478

Kiene RP (1988) Dimethyl sulfide metabolism in salt marsh sediments. FEMS Microbiol Lett 53:71-78

Kiene RP (1991) Production and consumption of methane in aquatic systems. In: Rogers JE, Whitman WB (eds) Microbial production and consumption of greenhouse gases: methane, nitrogen oxides and halomethanes. American Society for Microbiology, Washington, DC, p 111-146

Lamontagne RA, Swinnerton JW, Linnenboom VJ, Smith WD (1973) Methane concentration in various marine environments. J Geophys Res 78:5317-5324

Leadbetter JR, Crosby LD, Berznak JA (1998) Methnobrevibacter filiformis sp. nov.: a filamentous methanogen from termite hindguts. Arch Microbiol 169:287-292

Leftley JW, MacDougall N (1991) The Dunstaffnage sediment trap and its moorings. In: DML Internal Report, No. 174. Dunstaffnage Marine Lab, Oban, p 8

Ludwig W, Strunk O, Westram R, Richter L and others (2004) ARB: a software environment for sequence data. Nucleic Acids Res 32:1363-1371

> Liu Y, Whitman WB (2008) Metabolic, phylogenetic, and ecological diversity of the methanogenic Archaea. Ann NY Acad Sci 1125:171-189

Marty DG (1993) Methanogenic bacteria in seawater. Limnol Oceanogr 38:452-456
Marty DG, Nival P, Yoon WD (1997) MethanoArchaea associated with sinking particles and zooplankton collected in the northeastern tropical Atlantic. Oceanol Acta 20: 863-869

> Morales CE (1987) Carbon and nitrogen content of copepod faecal pellets: effect of food concentration and feeding behavior. Mar Ecol Prog Ser 36:107-114

Munson MA, Nedwell DB, Embley TM (1997) Phylogenetic diversity of Archaea in sediment samples from a coastal salt marsh. Appl Environ Microbiol 63:4729-4733

Oremland RS (1979) Methanogenic activity in plankton samples and fish intestines: a mechanism for in situ methanogenesis in oceanic surface waters. Limnol Oceanogr 24:1136-1141

> Paytan A, Cade-Menun B, McLaughlin K, Faul K (2003) Selective phosphorus regeneration of sinking marine particles: evidence from 31P-NMR. Mar Chem 82:55-70

> Ploug H, Jørgensen BB (1999) A net-jet flow system for mass transfer and microsensor studies of sinking aggregates. Mar Ecol Prog Ser 176:279-290

Ploug H, Kühl M, Buchholz-Cleven B, Jørgensen BB (1997) Anoxic aggregates - an ephemeral phenomenon in the pelagic environment? Aquat Microb Ecol 13:285-294

Purdy KJ, Nedwell DB, Embley TM (2003) Analysis of the sulfate-reducing bacterial and methanogenic Archaeal populations in contrasting Antarctica sediments. Appl Environ Microbiol 69:3181-3191

Saitou N, Nei M (1987) The neighbor-joining method: a new method for reconstructing phylogenetic trees. Mol Biol Evol 4:406-425

Scranton M, Brewer P (1977) Occurrence of methane in the near-surface waters of the western subtropical North Atlantic. Deep-Sea Res 24:127-138

Shanks AL, Reeder ML (1993) Reducing microzones and sulfide production in marine snow. Mar Ecol Prog Ser 96: $43-47$

Sieburth JM (1987) Contrary habitats for redox-specific processes: methanogenesis in oxic waters and oxidation in anoxic waters. In: Sliegh MA (ed) Microbes in the sea. Series in Marine Sciences, Ellis Horwood, Chichester, p 11-38

Sieburth JM, Donaghay PL (1993) Planktonic methane production and oxidation within the algal maximum of the pycnocline: seasonal fine-scale observations in an anoxic estuarine basin. Mar Ecol Prog Ser 100:3-15

> Sieburth JM, Johnson PW, Macario AJL, Demacario EC (1993) $\mathrm{C}_{1}$ bacteria in the water column of Chesapeake Bay, USA. II. The dominant $\mathrm{O}_{2}$ - and $\mathrm{H}_{2} \mathrm{~S}$-tolerant methylotrophic methanogens, coenriched with their oxidative and sulphate reducing bacterial consorts, are all new immunotypes and probably include new taxa. Mar Ecol Prog Ser 95:81-89

Simon M, Grossart HP, Schweitzer B, Ploug H (2002) Microbial ecology of organic aggregates in aquatic ecosystems. Aquat Microb Ecol 28:175-211

Sprenger WW, Hackstein HP, Keltjens JT (2007) The competition success of Methanomicrococcus blatticola, a dominant methylotrophic methanogen in the cockroach hindgut, is supported by high substrate affinities and favorable thermodynamics. FEMS Microbiol Ecol 60: 266-275

Tang KW, Glud RN, Glud A, Rysgaard S, Nielsen TG (2011) Copepod guts as biogeochemical hotspots in the sea: evidence from microelectrode profiling of Calanus spp. Limnol Oceanogr 56:666-672 
Tholen A, Pester M, Brune A (2007) Simultaneous methanogenesis and oxygen reduction by Methanobrevibacter cuticularis at low oxygen fluxes. FEMS Microbiol Ecol 62:303-312

Tilbrook BD, Karl DM (1995) Methane sources, distributions and sinks from California coastal waters to the oligotrophic North Pacific gyre. Mar Chem 49:51-64

Traganza ED, Swinnerton JW, Cheek CH (1979) Methane supersaturation and ATP-zooplankton blooms in nearsurface waters of the Western Mediterranean and the subtropical North Atlantic Ocean. Deep-Sea Res Part A 26:1237-1245

Tsai YL, Olson BH (1991) Rapid method for direct extraction of DNA from soil and sediments. Appl Environ Microbiol 57:1070-1074

van der Maarel MJ, Artz RR, Haanstra R, Forney LJ (1998) Association of marine Archaea with the digestive tracts of two marine fish species. Appl Environ Microbiol 64: 2894-2898

Editorial responsibility: Antje Boetius, Bremen, Germany van der Maarel M, Sprenger W, Haanstra R, Forney LJ (1999) Detection of methanogenic Archaea in seawater particles and the digestive tract of a marine fish species. FEMS Microbiol Lett 173:189-194

Wagner A, Blackstone N, Cartwright P, Dick M and others (1994) Surveys of gene families using polymerase chain reaction: PCR selection and PCR drift. Syst Biol 43: 250-261

Ward BB, Kilpatrick KA, Novelli PC, Scranton MI (1987) Methane oxidation and methane fluxes in the ocean surface layer and deep anoxic waters. Nature 327: 226-229

Whitman WT, Bowen T, Boone D (2006) The methanogenic bacteria. In: Dworkin W, Falkow S, Rosenberg E, Schleifer KH, Stackebrandt E (eds) The prokaryotes, Vol 3, 3rd edn. Springer, New York, NY, p 1165-1207

Wilson S (2007) The production of biogenic gases in the marine environment. $\mathrm{PhD}$ thesis, Scottish Association for Marine Science, UHI Millennium Institute, Scotland

Submitted: October 5, 2011; Accepted: July 12, 2012

Proofs received from author(s): August 29, 2012 